\title{
Factors associated with levels of empathy among students and professionals in the health field: a systematic review
}

\author{
Madson A. Maximiano-Barreto, ${ }^{1}$ (D) Daiene de M. Fabrício, ${ }^{2}$ (D) Bruna M. Luchesi, ${ }^{3}$ (D) Marcos H. N. Chagas ${ }^{1,2}$ (D)
}

\begin{abstract}
Objective: This study aimed to investigate factors associated with empathy and identify instruments used to measure this ability in professionals and students in the health field.

Method: A systematic review was performed. Searches were conducted on the PsycINFO, PubMed, Web of Science, and Scopus databases using the keywords "empathy" and "health professional". We selected 29 articles published in English, with no restriction imposed regarding the year of publication.

Results: Based on the findings of the articles selected, sociodemographic factors (female gender, being married, being older, having siblings, and having children) are associated with higher levels of empathy. Professional experience (years of practice) and being on the final years of the course also contributed to higher levels of empathy. Different versions of the Jefferson Scale of Empathy were the most prevalent assessment tools employed in the different studies.

Conclusion: The articles analyzed describe several factors that influence the level of empathy among health professionals and students. Thus, future studies should take sociodemographic factors into account when evaluating levels of empathy in this population.

Keywords: Empathy, health professional, health student.
\end{abstract}

\section{Introduction}

Empathy is a multidimensional phenomenon consisting of both cognitive and affective aspects. Cognitive empathy consists of the ability to understand the experience of others and communicate. ${ }^{1,2}$ Roche \& Harmon $^{2}$ characterize cognitive empathy as emotional resonance; it is how individuals see others through observations. Affective empathy is how an individual understands the emotions of others. Falcone et al. ${ }^{3}$ define affective empathy as concern and compassion.

Authors describe empathy as an emotional response directed between one individual and another by which both are able to feel the same emotion. It is the psychological result of the exchange of an experience between two individuals through functional disposition in an absolute manner, resulting in an evolving concern with regards to the situation of others. Thus, empathetic individuals are possibly capable of placing themselves in the position of others and experiencing emotions and feelings stemming from other individuals, thereby understanding the needs of others based on their motivations. ${ }^{3-5}$

Empathy involves emotional intelligence and good communication skills in all types of settings, as it is also related to good social skills. ${ }^{6}$ In health professionals, such as psychotherapists, higher levels of empathy can lead to a better relationship between patients/clients and professionals. ${ }^{7}$

\footnotetext{
${ }^{1}$ Departamento de Gerontologia, Universidade Federal de São Carlos (UFSCar), São Carlos, SP, Brazil. ${ }^{2}$ Departamento de Psicologia, UFSCar, São Carlos, SP, Brazil. ${ }^{3}$ Graduação em Medicina, Campus de Três Lagoas, Universidade Federal de Mato Grosso do Sul (UFMS), Três Lagoas, MS, Brazil. Submitted May 02 2019, accepted for publication Nov 222019.

Suggested citation: Maximiano-Barreto MA, Fabrício DM, Luchesi BM, Chagas MHN, et al. Factors associated with levels of empathy among students and professionals in the health field: a systematic review. Trends Psychiatry Psychother. 2020;42(2):207-215. http://dx.doi.org/10.1590/2237-6089-2019-0035
} 
It is important to note that empathetic skills contribute to greater adherence to treatment and ease of communication, allowing patients to express their doubts, symptoms, and other elements. ${ }^{7,8}$ Indeed, health and educational policies for health professionals often describe the importance of having empathy, ${ }^{9}$ as this ability enables stronger professional-patient relationships and assists in understanding the needs of each individual. ${ }^{10}$

According to Sampaio et al., ${ }^{11}$ there are several ways to evaluate empathy, such as physiological methods, analysis of facial expressions, and self-assessments. Self-assessment instruments are more frequent in the literature because they are practical, reliable, and offer ease of measurement. ${ }^{11}$ The most common scales for assessment of empathy are the Feshbach and Roe Affective Situation Test for Empathy, the Interpersonal Perception Test, the Empathy Continuum Scoring System, the Empathy Scale, the Affective Perspective-Taking Task, and the Interpersonal Reactivity Index. ${ }^{12}$ The most widely used of these is the Interpersonal Reactivity Index. ${ }^{11}$ The aim of these instruments is to evaluate empathy in the two aforementioned dimensions.

This ability can help to improve the work of health professionals, such as therapists. According to Reik, ${ }^{13}$ a therapist's main tool is his/her personality, through which the therapist can understand what is needed to adequately carry out his/her work. Empathy is also important for developing a good relationship with the patient, providing and receiving feedback, ${ }^{6}$ and behaving in such a way as to enable patients to describe their problems and symptoms and ask questions in a safe environment. ${ }^{14}$ According to Gadamer, ${ }^{8}$ it is extremely important for diagnostic and therapeutic processes that patients attain familiarity and a feeling of being safe when in the presence of health professionals.

Therefore, the aim of the present study was to investigate factors associated with empathy and identify instruments used to assess this skill among professionals and students in the health field.

\section{Methods}

The present systematic review of the literature was conducted in accordance with the Preferred Reporting Items for Systematic Reviews and Meta-Analyses (PRISMA) statement. ${ }^{15}$ Searches were conducted on the PsyciNFO, PubMed, Web of Science, and Scopus databases for pertinent articles using the following search terms: "empathy" and "health professional."

The inclusion criteria were articles evaluating empathy in health professionals and students and quantitative studies published in English. No restriction was imposed with regards to the year of publication. The exclusion criteria were validation studies, experimental and case-control studies, editorials, literature reviews, letters to the editor, and dissertations.

Two authors independently searched the databases between November and December of 2018. At this stage, the following information was extracted from the articles and noted: author and year of publication, study design, study setting, sample size, sociodemographic characteristics of the sample, instruments used to assess empathy, and results. In cases in which there were doubts regarding inclusion or exclusion of an article, a meeting was held with all authors and a consensus was reached.

Pre-selection was performed by analysis of titles and abstracts. The Mendeley ${ }^{\circledR}$ software program was used to assist in retrieval of manuscripts and identification of duplicated references. Articles that met the eligibility criteria were subjected to full-text analysis. The reviewers then performed manual searches of the reference lists of the selected articles to identify further relevant articles to include in the review. Figure 1 presents a flowchart illustrating the search process.

The baseline characteristics of the studies were evaluated for individual quality. A tool for crosssectional studies was used for this task. ${ }^{16}$ This tool comprises ten items for evaluation of external validity, selection, response bias, internal validity, measurement bias, and analysis. Based on the final score awarded, studies were classified as having low risk (0 to 3 points), moderate risk (4 to 6 points) or high risk ( 7 to 9 points) of bias.

\section{Results}

A total of 730 articles were identified in the databases using the search terms. Tables 1 and 2 list data from the 29 articles selected for inclusion in this systematic review. Table 1 contains studies that assess empathy using the Jefferson scale and Table 2 presents studies that used other instruments to assess this ability.

The risk of bias analysis identified $\mathrm{two}^{17,18}$ of the 29 articles as having a moderate risk of bias, while all others scored between 0 and 3 (low risk). No articles were therefore excluded from the review because of risk of bias. Two articles with longitudinal designs were included in the sample. We analyzed the main methodological bases of these designs to measure quality. For the studies that had a moderate risk of bias, the items scored were: use of small samples that did not represent the national population and convenience 
sample selection. Additionally, the final analyses showed that the non-response bias of the studies was $<75 \%$.

\section{Characteristics of selected studies}

A total of 22,329 professionals and students in the health field participated in the selected studies. The number of individuals in each study ranged from $40^{19}$ to $7584 .^{20}$ Twenty-one studies had greater participation of female health professionals and/or students. ${ }^{17,19,21-39}$ Regarding the age of the interviewees, Petrucci et al. ${ }^{19}$ reported the lowest mean ( $\bar{X}=21.27$ years; standard deviation $[S D]=3.32$ ) and Charles et al. ${ }^{40}$ reported the highest $(\bar{X}=55.91$ years; $S D=7.68)$.

In terms of setting, 10 studies were conducted at hospitals, ${ }^{19,21,22,30,35,41-45} 10$ were conducted at universities, ${ }^{18,23-29,35,39}$ two were conducted at both hospitals and universities, ${ }^{32,38}$ and the remainder used online surveys. ${ }^{17,20,31,34,36,37,40}$ Regarding study design, two types of design were identified among the articles selected: cross-sectional and longitudinal. Most ( $\mathrm{n}=$ 27) were cross-sectional studies ${ }^{17,19-31,33-45}$ and only two were longitudinal studies. ${ }^{18,32}$

The professionals and students were from the following health fields: nursing, medicine, physical therapy, occupational therapy, psychology, pharmacy, social services, midwifery, health science, paramedicine, dentistry, speech therapy, and others. The most prevalent field was medicine, ${ }^{20-26,28-30,33,36,38,45}$ followed by nursing, ${ }^{19,21-24,29,30,35,36,45}$ and psychology. $21,22,24,37,41$ Eleven studies involved participation of students, ${ }^{18,23-29,33,39,42}$

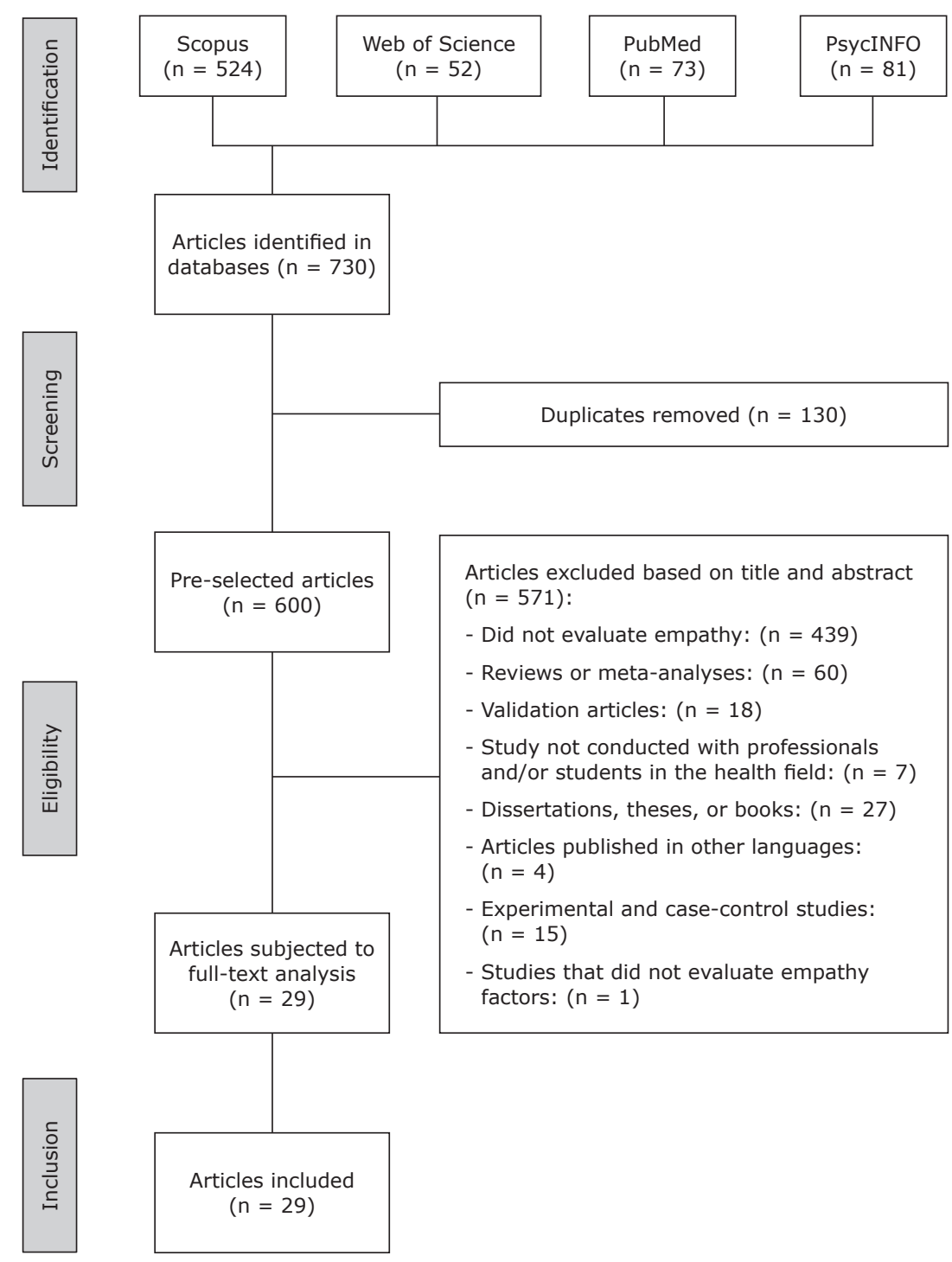

Figure 1 - Flowchart following recommendations of PRISMA initiative. Excerpted from Moher et al. ${ }^{15}$ 
Empathy in students and professionals in the health field - Maximiano-Barreto et al.

Table 1 - Studies that evaluated empathy using the Jefferson Scale

\begin{tabular}{|c|c|c|c|c|c|c|c|c|c|c|}
\hline Reference & Year & $\mathbf{N}$ & Sex $(\%)$ & $\frac{\text { Age }}{(\bar{X} ; \text { SD })}$ & Setting & Country & Design & Participants & $\begin{array}{c}\text { Empathy } \\
\text { instrument }\end{array}$ & Outcome \\
\hline $\begin{array}{l}\text { Bourgault } \\
\text { et al. }{ }^{19}\end{array}$ & 2012 & 29 & $F(90)$ & ND & Hospital & Canada & Cross-sectional & Nurses & JSPE & $\begin{array}{l}\text { Older professionals had higher } \\
\text { levels of empathy. }\end{array}$ \\
\hline $\begin{array}{l}\text { Boyle et } \\
\text { al. }\end{array}$ & 2010 & 469 & $F(81.3)$ & ND & University & Australia & Cross-sectional & $\begin{array}{l}\text { Midwifery, } \\
\text { occupational therapy, } \\
\text { physical therapy, } \\
\text { health science }\end{array}$ & JSE-HP & $\begin{array}{l}\text { Female and older students had } \\
\text { more empathy. Students of } \\
\text { occupational therapy had higher } \\
\text { levels of empathy. }\end{array}$ \\
\hline $\begin{array}{l}\text { Brown et } \\
\text { al. }{ }^{39}\end{array}$ & 2010 & 92 & $F(91.3)$ & ND & University & Australia & Cross-sectional & $\begin{array}{l}\text { Students of } \\
\text { occupational therapy }\end{array}$ & JSPE & $\begin{array}{l}\text { There was no difference in the } \\
\text { variables age, sex, or year of } \\
\text { schooling in relation to empathy. }\end{array}$ \\
\hline $\begin{array}{l}\text { Charles et } \\
\text { al. } 40\end{array}$ & 2018 & 474 & $F(45,6)$ & $\begin{array}{l}55.91 \\
7.86\end{array}$ & Online & Denmark & Cross-sectional & Physicians & JSE-HP & $\begin{array}{l}\text { The physician-patient relationship, } \\
\text { colleagues, and satisfaction with } \\
\text { work increase levels of empathy. }\end{array}$ \\
\hline $\begin{array}{l}\text { Cripe et } \\
\text { al. } 44\end{array}$ & 2017 & 134 & $F(40,3)$ & ND & Hospital & $\begin{array}{l}\text { United } \\
\text { States }\end{array}$ & Cross-sectional & Physicians & JSE-HP & $\begin{array}{l}\text { Time on course did not lead to } \\
\text { differences in levels of empathy. }\end{array}$ \\
\hline $\begin{array}{l}\text { Daw \& } \\
\text { Joseph }\end{array}$ & 2010 & 49 & $F(79.1)$ & 43.9 & Online & $\begin{array}{l}\text { United } \\
\text { Kingdom }\end{array}$ & Cross-sectional & Psychologists & JSE-HP & $\begin{array}{l}\text { Therapists with higher levels of } \\
\text { psychological mentality (thinking, } \\
\text { feeling, and behavior) had higher } \\
\text { levels of empathy. }\end{array}$ \\
\hline $\begin{array}{l}\text { Fields et } \\
\text { al. }\end{array}$ & 2004 & 98 & $F(100)$ & ND & Hospital & $\begin{array}{l}\text { United } \\
\text { States }\end{array}$ & Cross-sectional & $\begin{array}{l}\text { Physicians and } \\
\text { nurses }\end{array}$ & JSPE & $\begin{array}{l}\text { No difference between physicians } \\
\text { and nurses regarding level of } \\
\text { empathy. }\end{array}$ \\
\hline $\begin{array}{l}\text { Hojat et } \\
\text { al. }{ }^{18}\end{array}$ & 2005 & 106 & $F(44.5)$ & ND & University & $\begin{array}{l}\text { United } \\
\text { States }\end{array}$ & Longitudinal & Medical students & JSPE & $\begin{array}{l}\text { Higher levels of empathy over the } \\
\text { years of the course. }\end{array}$ \\
\hline $\begin{array}{l}\text { Hsiao \& } \\
\text { Tsai }^{30}\end{array}$ & 2015 & 175 & $F(88.6)$ & $\begin{array}{l}32.53 \\
6.46\end{array}$ & Hospital & Taiwan & Cross-sectional & Nurses & JSE-HP & $\begin{array}{l}\text { Nurses with more experience had } \\
\text { higher levels of empathy. }\end{array}$ \\
\hline $\begin{array}{l}\text { Mahoney } \\
\text { et al. }{ }^{32}\end{array}$ & 2016 & 281 & $F(58)$ & ND & $\begin{array}{l}\text { University } \\
\text { and } \\
\text { Hospital }\end{array}$ & Australia & Longitudinal & $\begin{array}{l}\text { Students of medicine } \\
\text { and medical } \\
\text { professionals }\end{array}$ & JSE & $\begin{array}{l}\text { Increase in empathy each year } \\
\text { among students and professionals. } \\
\text { No difference in levels of empathy } \\
\text { between groups. Females have } \\
\text { more empathy. }\end{array}$ \\
\hline $\begin{array}{l}\text { McKenna } \\
\text { et al. }{ }^{25}\end{array}$ & 2012 & 106 & $F(92.5)$ & ND & University & Australia & Cross-sectional & Nursing students & JSE-HP & ND \\
\hline $\begin{array}{l}\text { Park et } \\
\text { al. }{ }^{43}\end{array}$ & 2016 & 317 & $F(67.5)$ & $\begin{array}{c}30.45 \\
2.98\end{array}$ & Hospital & Korea & Cross-sectional & Physicians & JSE-HP-K & $\begin{array}{l}\text { Female professionals, married } \\
\text { individuals, those with siblings, } \\
\text { and children had higher levels of } \\
\text { empathy. }\end{array}$ \\
\hline $\begin{array}{l}\text { Penšek \& } \\
\text { Selič } 37\end{array}$ & 2018 & 316 & $F(81.9)$ & $\begin{array}{c}40 ; \\
10.2\end{array}$ & Online & Slovenia & Cross-sectional & Physicians & JSE-HP & $\begin{array}{l}\text { Female professionals had higher } \\
\text { levels of empathy. }\end{array}$ \\
\hline $\begin{array}{l}\text { Petrucci et } \\
\text { al. }{ }^{33}\end{array}$ & 2016 & 512 & $F(66.4)$ & $\begin{array}{r}21.27 \\
3.32\end{array}$ & University & Italy & Cross-sectional & $\begin{array}{l}\text { Students of nursing } \\
\text { and other health } \\
\text { courses }\end{array}$ & JSE-HP & $\begin{array}{l}\text { Nursing students had higher levels } \\
\text { of empathy than students of other } \\
\text { health fields. Female students } \\
\text { exhibited more empathy than } \\
\text { male students. }\end{array}$ \\
\hline $\begin{array}{l}\text { San-Martín } \\
\text { et al. }{ }^{45}\end{array}$ & 2017 & 354 & ND & ND & Hospital & $\begin{array}{l}\text { Mexico, } \\
\text { Colombia, } \\
\text { Ecuador, } \\
\text { and } \\
\text { Argentina }\end{array}$ & Cross-sectional & $\begin{array}{l}\text { Physicians and } \\
\text { nurses }\end{array}$ & JSE-HP & $\begin{array}{l}\text { Physicians had higher levels of } \\
\text { empathy. }\end{array}$ \\
\hline $\begin{array}{l}\text { Shariat \& } \\
\text { Habibi }^{26}\end{array}$ & 2013 & 1187 & $F(63.6)$ & $\begin{array}{c}22.6 \\
2.8\end{array}$ & University & Iran & Cross-sectional & Medical students & JSE & $\begin{array}{l}\text { Level of empathy was higher in } \\
\text { females. Higher level of schooling } \\
\text { associated with higher level of } \\
\text { empathy. }\end{array}$ \\
\hline $\begin{array}{l}\text { Wang et } \\
\text { al. }{ }^{35}\end{array}$ & 2017 & 251 & $F(96.2)$ & $\begin{array}{c}26.98 \\
4.00\end{array}$ & Hospital & China & Cross-sectional & Nurses & JSE-HP & $\begin{array}{l}\text { Professionals with more } \\
\text { experience, married individuals, } \\
\text { and those with children had higher } \\
\text { levels of empathy. }\end{array}$ \\
\hline $\begin{array}{l}\text { Williams et } \\
\text { al.27 }\end{array}$ & 2013 & 94 & $F(62.8)$ & ND & University & Australia & Cross-sectional & Paramedical students & JSPE & $\begin{array}{l}\text { Level of empathy higher among } \\
\text { males, those with higher level of } \\
\text { schooling, and older individuals. }\end{array}$ \\
\hline $\begin{array}{l}\text { Williams et } \\
\text { al. }{ }^{28}\end{array}$ & 2014 & 1111 & $F(81.6)$ & ND & University & Australia & Cross-sectional & $\begin{array}{l}\text { Students of } \\
\text { midwifery, nursing, } \\
\text { paramedicine, } \\
\text { occupational therapy, } \\
\text { physical therapy, and } \\
\text { nutrition }\end{array}$ & JSE-HP & $\begin{array}{l}\text { Female and older students } \\
\text { exhibited higher levels of empathy. }\end{array}$ \\
\hline $\begin{array}{l}\text { Zhang et } \\
\text { al. }^{21}\end{array}$ & 2017 & 4125 & $F(97.4)$ & $\begin{array}{c}29.37 \\
618\end{array}$ & Hospital & China & Cross-sectional & Nurses & JSE-HP & $\begin{array}{l}\text { Less experienced professionals, } \\
\text { those who work in the emergency } \\
\text { wards, and those on the swing } \\
\text { shift have lower levels of empathy. }\end{array}$ \\
\hline
\end{tabular}

$\mathrm{CG}=$ control group; $\mathrm{F}=$ female; IG = intervention group; JSE = Jefferson Scale of Empathy; JSE-HP = Jefferson Scale of Physician Empathy Health; JSE-HP-K = Jefferson Scale of Physician Empathy - Health Professional - Korean; JSPE = Jefferson Scale of Physician Empathy; $M=$ male ND = not declared; SD = standard deviation; $\overline{\mathrm{X}}$ : mean. 
Table 2 - Studies that evaluated empathy using other instruments

\begin{tabular}{|c|c|c|c|c|c|c|c|c|c|c|}
\hline Reference & Year & $\mathbf{N}$ & $\begin{array}{l}\text { Sex } \\
(\%)\end{array}$ & $\frac{\text { Age }}{(\bar{X} ; \text { SD })}$ & Setting & Country & Design & Participants & $\begin{array}{c}\text { Empathy } \\
\text { instrument }\end{array}$ & Outcome \\
\hline $\begin{array}{l}\text { Gleichgerrcht } \\
\& \text { Decety }\end{array}$ & 2013 & 7584 & $F(46.5)$ & $44.6 ; 12.1$ & Online & Argentina & Cross-sectional & Physicians & IRI & $\begin{array}{l}\text { Older professionals, those } \\
\text { with more experience, and } \\
\text { those of the female sex had } \\
\text { higher levels of empathy. }\end{array}$ \\
\hline $\begin{array}{l}\text { Gleichgerrcht } \\
\& \text { Decety }{ }^{41}\end{array}$ & 2014 & 1119 & $F(48.5)$ & $47.5 ; 11.8$ & Hospital & Argentina & Cross-sectional & Physicians & IRI & $\begin{array}{l}\text { Older professionals and } \\
\text { those with more experience } \\
\text { have more empathy. }\end{array}$ \\
\hline Jurado et al. ${ }^{36}$ & 2018 & 719 & $F(84.3)$ & $38.53 ; 9.46$ & Online & Chile & Cross-sectional & $\begin{array}{l}\text { Physicians, } \\
\text { physiotherapists, } \\
\text { nursing assistants, and } \\
\text { other health positions }\end{array}$ & BES & $\begin{array}{l}\text { Physicians had higher } \\
\text { levels of empathy. }\end{array}$ \\
\hline Khan et al. ${ }^{42}$ & 2016 & 300 & $F(50)$ & ND & Hospital & Pakistan & Cross-sectional & Medical students & EES & $\begin{array}{l}\text { Students with good } \\
\text { emotional intelligence have } \\
\text { higher levels of empathy. }\end{array}$ \\
\hline Love et al. ${ }^{31}$ & 2015 & 92 & $F(66.3)$ & $36.0 ; 12.13$ & Online & $\begin{array}{l}\text { United } \\
\text { States }\end{array}$ & Cross-sectional & $\begin{array}{l}\text { Psychologists, clinical } \\
\text { psychologists, } \\
\text { counselors, marriage } \\
\text { therapists, social } \\
\text { assistants }\end{array}$ & IRI & ND \\
\hline $\begin{array}{l}\text { Özakgül et } \\
\text { al. }\end{array}$ & 2014 & 614 & $F(79)$ & ND & University & Turkey & Cross-sectional & Nursing students & SET & $\begin{array}{l}\text { Female students had a } \\
\text { higher level of empathy. }\end{array}$ \\
\hline $\begin{array}{l}\text { Putrino et } \\
\text { al. }^{38}\end{array}$ & 2018 & 126 & $F(70.6)$ & $\begin{array}{c}\text { PMG: } 34.73 \\
\pm 6.06 ; \\
\text { PPG: } 35.35 \\
\pm 7.24 ; \\
\text { SPG: } 23.88 \\
\pm 7.23 ; \\
\text { SMG: } 19.4 \\
\pm 2.22\end{array}$ & $\begin{array}{l}\text { University } \\
\text { and } \\
\text { hospital }\end{array}$ & Argentina & Cross-sectional & $\begin{array}{l}\text { Professionals and } \\
\text { students of medicine } \\
\text { and psychology }\end{array}$ & IRI & $\begin{array}{l}\text { Students had a higher level } \\
\text { of empathy. Students of } \\
\text { psychology had a higher } \\
\text { level of empathy. }\end{array}$ \\
\hline $\begin{array}{l}\text { Santamaría- } \\
\text { García et al. }{ }^{34}\end{array}$ & 2017 & 1109 & $F(52.1)$ & $37.61 ; 12.5$ & Online & $\begin{array}{c}\text { Argentina, } \\
\text { Mexico, } \\
\text { Colombia, } \\
\text { Peru, } \\
\text { Ecuador, } \\
\text { Uruguay, } \\
\text { Chile, } \\
\text { Paraguay, } \\
\text { Bolivia }\end{array}$ & Cross-sectional & $\begin{array}{l}\text { Physicians, } \\
\text { psychologists, and } \\
\text { other professionals }\end{array}$ & IRI & $\begin{array}{l}\text { Professionals with more } \\
\text { experience, physicians, } \\
\text { females, and older } \\
\text { individuals had higher } \\
\text { levels of empathy. }\end{array}$ \\
\hline Rasoal et al. ${ }^{23}$ & 2009 & 365 & $F(78)$ & $25.2 ; 5.7$ & University & Sweden & Cross-sectional & $\begin{array}{l}\text { Students of medicine, } \\
\text { psychology, } \\
\text { nursing and social } \\
\text { services; students of } \\
\text { paramedicine, nursing }\end{array}$ & IRI & $\begin{array}{l}\text { Female students, first year } \\
\text { students, and those on } \\
\text { the psychology course had } \\
\text { higher levels of empathy }\end{array}$ \\
\hline
\end{tabular}

$\mathrm{BES}=$ Basic Empathy Scale; EES = Emotional Empathy Scale; $\mathrm{F}=$ female; $\mathrm{IRI}=$ interpersonal reactivity index; $\mathrm{M}=$ male; $\mathrm{ND}=$ not declared; SD = standard deviation; $\bar{X}=$ mean.

15 were conducted with professionals, $17,20-22,29-$ $31,34,35,37,40,41,43-45$ and two were conducted with both professionals and students. ${ }^{32,38}$

\section{Assessment of empathy}

Ten instruments were used for assessment of empathy: the Jefferson Scale of Physician Empathy (JSPE), 18,19,22,27 the Jefferson Scale of Empathy (JSE), ${ }^{26,32}$ the Jefferson Scale of Empathy for Health Professionals (JSE-HP) 17,21,24,25,28,30,33,35,37,39,40,43-45 (Table 1), the Interpersonal Reactivity Index (IRI), 20,23,31,34,38,41 and other instruments. ${ }^{29,36,42}$ (Table 2). Rasoal et al. ${ }^{23}$ employed two empathy assessment tools. For all instruments, the level of empathy is determined by the total number of points per individual interviewed, with greater scores denoting a higher level of empathy.

The JSE has been validated for many different $c$ ontexts. ${ }^{17,21,24,25,30,33,35,37,39,40,43-45}$ The JSE and JSPE ${ }^{46}$ were developed for assessment of empathy in medical students and physicians, whereas the JSE-HP was developed for health professionals. Both are self-report instruments with 20 items scored on a seven-point Likert scale ( 1 = I strongly disagree; 7 = I strongly agree). The total score ranges from 20 to 140 points. However, in the Korean version (JSE-HP-K) two questions were removed based on the evaluation of the items and their reliability, resulting in a total score ranging from 18 to 126 points.

These scales have three components ("perspective taking", "compassionate care" and "standing in the patient's shoes"). The major difference between the physician and health professional versions is that the JSE-HP was developed to evaluate empathetic behavior among health professionals, whereas the JSE and JSPE evaluate empathetic attitudes. ${ }^{46}$ Although the terms empathetic behavior and empathetic attitude are 
correlated, the JSE-HP was developed to evaluate the actions of health professionals, whereas the JSE and JSPE address the perceptions of medical students and physicians. ${ }^{47}$

The IRI, developed by Davis, ${ }^{48}$ evaluates two main domains of empathy (affective and cognitive). This instrument has 16 items, each with five response options scored from 1 to 5. The Basic Empathy Scale developed by Jolliffe \& Farrington ${ }^{49}$ and the Scale of Empathetic Tendency developed by Dökmen ${ }^{50}$ address the same domains as the IRI and also have five response options per item, but the scales are composed of 20 items. Mehrabian \& Epstein ${ }^{51}$ developed the Measure of Emotional Empathy, which assesses three domains (tendency to be moved by the emotional experiences of others, emotional responsiveness, and susceptibility to emotional contagion) and has 33 items scored on a Likert scale from 1 to 7 points.

\section{Level of empathy among health professionals and students}

The variety of instruments used for assessment of empathy among health professionals and/or students led to variations in the results. Among the studies conducted with both professionals and students, ${ }^{32,38}$ only the study by Putrino et al. ${ }^{38}$ found that students had higher levels of empathy than professionals. Among the studies conducted only with professionals, two ${ }^{36,42}$ found that physicians had higher levels of empathy compared to professionals from other fields. Among the students, those on occupational therapy, ${ }^{24}$ nursing, ${ }^{33}$ and psychology 23,38 courses had higher levels of empathy than students studying other fields of health.

Among the studies conducted with health professionals only, eight $20,21,30,34,35,38,40,41$ evaluated the association between professional experience and empathy, six of which $20,21,30,34,35,41$ demonstrated that more experienced professionals had higher levels of empathy. Ten studies $18,23-27,29,32,39,44$ evaluated the association between time on the course and empathy among students, one of which ${ }^{23}$ found that students at the start of the course had more empathy, whereas four $18,26,27,32$ found higher levels of empathy among students at the end of their courses.

Other factors were identified as associated with increased levels of empathy, such as sex, age, and marital status. Seventeen studies ${ }^{17,18,20,23-26,28,29,32-34,37,38,40,41,43}$ evaluated the association with sex and 11 identified females as having higher levels of empathy than males, $20,23,24,26,28,29,32-34,37,43$ whereas two studies 27,35 found higher levels of empathy among males. Regarding age, 11 studies $^{19,20,24,25,27-29,33,34,39,41}$ compared older and younger professionals and/or students and seven $20,24,27-29,34,41$ found that being older contributed to higher levels of empathy. Wang et al. ${ }^{35}$ and Park et al. ${ }^{43}$ analyzed the association with marital status and found that being married contributed to higher levels of empathy. The same authors found that having children also contributed to higher levels of empathy and Park et al. ${ }^{43}$ found that having siblings contributed to increased empathy.

\section{Discussion}

The results of the selected studies demonstrate a gamut of factors that influence the level of empathy among health professionals and students. Empathy is a social skill that has been described in different fields of knowledge, particularly in the health field, and we identified studies with diverse objectives related to empathy. ${ }^{17-45}$ This skill can have positive consequences, such as pleasant relationships and a reduction in conflicts. ${ }^{52}$

In the context of health, empathy is related to the practice of humanization. ${ }^{53}$ Empathy has a direct association with diagnostic and therapeutic results, as described in the introduction to this article. Moreover, it enables better communication ${ }^{54}$ and attention on the part of health professionals toward their patients, not only in the health-illness process, but in all aspects that affect the individual. ${ }^{13,14}$ This extends to all health professionals and students.

Another point that merits mention is related to the higher level of empathy among females compared to males, which may be related to biological and physiological factors. Derntl et al. ${ }^{55}$ found that, when compared to men in an activity involving three domains of empathy (emotion recognition, perspective-taking, and affective responsiveness), women had stronger neural activations in regions of emotion, including the amygdala. Moreover, a longitudinal study in adolescents conducted in two waves found that females exhibit a faster increase in empathy than males. ${ }^{56}$ Studies conducted with health professionals have demonstrated that women have more positive attitudes toward their patients. ${ }^{57-59}$

A number of studies have investigated associations between socio-demographic factors (sex, marital status, having children, having siblings, etc.) and empathy. ${ }^{20,23,24,26-29,32-35,37,41,43,60}$ In addition to female sex, having children and siblings can contribute positively to greater empathy 35,43 and socioemotional development. ${ }^{61,62}$ With regard to marital status, studies in the present review found that married health professionals had higher levels of empathy than single individuals. ${ }^{35,43}$ Similar findings are described in other 
studies. ${ }^{63-65}$ Although the factors that influence the level of empathy are not modifiable, experimental studies show that training interventions can change this scenario. ${ }^{66-68}$

A vast gamut of instruments are used to assess empathy, some of which are widely employed on the international level, such as the Interpersonal Reactivity Index (IRI), ${ }^{51}$ Basic Empathy Scale (BES), ${ }^{69}$ and Jefferson Scale of Empathy (JSE). ${ }^{46}$ The widespread use of different versions of the Jefferson Scale (JSE-S, JSE-HP, and JSPE) may be because of the target public, that is, health professionals or students. Accordingly, Hemmerdinger et al. ${ }^{70}$ identified greater use of the JSPE among studies conducted with students of medicine and medical professionals. On all instruments, empathy is assessed using Likert scales ${ }^{17-45}$ ranging from four to nine points, with higher scores denoting a higher level of empathy. This format is unanimous among all scales identified in the results of the present review. Despite the use of several instruments to assess empathy in the selected studies, it seems that there are no differences in outcomes depending on the scales used. For example, the studies show that female individuals have higher levels of empathy, regardless of the scale used. $20,23,24,26,28,29,32-34,37,43$

Previous studies found that the IRI was the most widely used scale for evaluation of empathy. 6,7 However, one of the objectives of the present review was to identify the instruments used to assess this skill in students and professionals in the health field and we found that the majority of articles included in this review used the JSE. This divergence may be explained by the fact that we only included studies with students and professionals in the health field and this scale contains specific items that address the physician-patient relationship.

The authors of a study carried out with students in the health field involving 150 nurses and 450 patients at a university in Iran found that the patients evaluated the students' service as being of high quality, generating responsiveness and the capacity to ensure empathy. ${ }^{71} A$ study by Madera-Anaya et al. ${ }^{72}$ reports similar results and these authors concluded that good teaching practices employed in the initial years of the undergraduate course increase the possibility of enhancing the level of empathy.

In contrast, another study involving participation of 320 university students that aimed to evaluate the gap between students' expectations and perceptions of educational services reported a negative evaluation of the quality of teaching and education to the point of exerting a negative impact on development of empathy. ${ }^{73}$ Other studies report similar findings, ${ }^{74,75}$ demonstrating that the educational structure may affect development of empathy ${ }^{76}$ among students in the health field as well as other fields of knowledge.

Besides the factors described above, the work environment, professional experience, relationships among colleagues, relationships with patients, and the sector in which the health professional works also exert an influence on increase or decrease in empathy. According to Zhang et al. ${ }^{21}$ Khan et al., ${ }^{42}$ and Heje et al., ${ }^{77}$ job satisfaction is directly related to empathy and sectors such as intensive care and the emergency ward can lead to psychological suffering due to the tension involved in the work, with a consequent lowering of empathy. ${ }^{19,35}$ In contrast, greater professional experience contributes to increasing the level of this social skill. 20,30,34,35,41

Experimental66-68 studies have demonstrated that activities such as workshops, dramatizations, online courses, and reflective writing enable increases in levels of empathy. Such activities have also been identified in studies presented by Batt-Rawden et al. ${ }^{76}$ as enabling an increase in the level of empathy. Among case-control studies ${ }^{78-80}$ conducted in both hospital and educational settings, only a study by Mathad et al. ${ }^{80}$ involving students found an increase in empathy in the intervention group compared to the control group.

Some of the articles that this systematic review included have limitations with regards to the way the studies were conducted. The following drawbacks were identified: cross-sectional design, $26,28,30,36,42$ which does not enable identification of causality; a longitudinal design $^{40}$ with re-administration of the empathy scale over a very large period of time; small sample size ${ }^{17,32,45}$; studies conducted at a single center ${ }^{18,32,38}$; studies with a single group, limiting generalization of the findings ${ }^{18}$; a large, very diversified sample ${ }^{45}$; use of a self-report scale $17,30,36,40$; and new psychometric validations of the JSE-HP for the public surveyed.22,28 Such drawbacks should be taken into consideration during design of future studies on this topic.

One limitation of the present systematic review was selection of only studies published in English, since articles published in other languages could have contributed to additional reflections on the influence of cultural issues on levels of empathy. The decision to select only articles in English was based on the fact that this language is the most common in the literature. Additionally, the choice of keywords may have influenced the articles found for this review. Inclusion of terms such as "nurses", "doctors", "students", and other specific terms, could have increased the number of articles found on the databases. 


\section{Conclusion}

Considering the results of the present systematic review, a gamut of factors can exert a positive influence on increased empathy among professionals and students in the field of health, such as professional experience, longer time on the undergraduate course, female sex, older age, being married, having children, and having siblings.

Regarding evaluation of empathy, we found that the Jefferson scale is widely used when the aim is to measure this skill in students and professionals in the health field. Finally, considering the importance of empathy, it is necessary to establish educational practices for development of empathy in teaching and professional settings, especially for clinicians/students who will be in direct contact with the emotional issues of their patients, such as therapists and psychiatrists.

\section{Acknowledgments}

This study was financed in part by the Brazilian academic funding agency Coordenação de Aperfeiçoamento de Pessoal de Nível Superior (CAPES; Finance Code 001).

\section{Disclosure}

No conflicts of interest declared concerning the publication of this article.

\section{References}

1. Pinho VDD, Fernandes CS, Falcone EMDO. A influência da idade e da escolaridade sobre a experiência empática de adultos. Estud Pesqui Psicol. 2011;11:456-71.

2. Roche J, Harmon D. Exploring the facets of empathy and pain in clinical practice: a review. Pain Practice. 2017;17:1089-96.

3. Falcone EMO, Ferreira MC, Luz RCM, Fernandes CS, Assis Faria C, D'Augustin JF, et al. Inventário de Empatia (I.E.): desenvolvimento e validação de uma medida brasileira. Aval Psicol. 2008;7:321-34.

4. Eisenberg $N$, Strayer J. Critical issues in the study of empathy. In: Eisenberg N, Strayer J, editors. Empathy and its development. Cambridge: Cambridge University Press; 1987. p. 3-13.

5. Formiga NS, Rocha MCO, Pinto ADSS, Reis DAD, Costa SMDS, Leime J. Fidedignidade da estrutura fatorial da Escala Multidimensional de Reatividade Interpessoal (EMRI). Est Intern Psicol. 2013;4:64-79.

6. Davis MH. Empathy: a social psychological approach. Boulder: Westview Press; 1994.

7. Fontgalland RC, Moreira V, Melo CDF. The experience of being empathic to the beginner humanistic-phenomenological psychotherapist. Arq Bras Psicol. 2018;70:5-20.

8. Gadamer HG. Dove si nasconde la salute. Milano: Raffaello Cortina; 1994.

9. McMillan LR, Shannon DM. Psychometric analysis of the JSPE nursing student version R: comparison of senior BSN students and medical students attitudes toward empathy in patient care. ISRN Nurs. 2011;2011:726063.

10. Neumann M, Bensing J, Mercer S, Ernstmann N, Ommen O, Pfaff $\mathrm{H}$. Analyzing the "nature" and "specific effectiveness" of clinical empathy: a theoretical overview and contribution towards a theory-based research agenda. Patient Educ Couns. 2009;74:33946.

11. Sampaio LR, Guimarães PRB, Santos CP, Formiga NS, Menezes IG. Estudos sobre a dimensinalidade da empatia: traduçao e adaptaçao do interpersonal reactivity index (IRI). Psico. 2011;42:67-76

12. Del Giudice M. Misurare le emozioni - una rassegna dei test più utilizzati nella ricerca sulle emozioni: caractteristiche, funzionamento, risultati empririci. Scienceopen. 2004:1-40.

13. Reik T. Listening with the third ear. New York: Farrer, Strauss and Young; 1948.

14. Halpern J. From detached concern to empathy: humanizing medical practice. New York: Oxford University Press; 2001.

15. Moher D, Liberati A, Tetzlaff J, Altman DG. Preferred reporting items for systematic reviews and meta-analyses: the PRISMA statement. Ann Intern Med. 2009;151:264-9.

16. Hoy D, Brooks P, Woolf A, Blyth F, March L, Bain C, et al. Assessing risk of bias in prevalence studies: modification of an existing tool and evidence of interrater agreement. J Clin Epidemiol. 2012;65:934-9.

17. Daw B, Joseph S. Psychological mindedness and therapist attributes. Couns Psychother Res. 2010;10:233-6.

18. Hojat M, Mangione S, Nasca TJ, Gonnella JS, Magee M. Empathy scores in medical school and ratings of empathic behavior in residency training 3 years later. J Soc Psychol. 2005;145:66372.

19. Bourgault P, Lavoie S, Paul-Savoie E, Grégoire M, Michaud C, Gosselin $E$, et al. Relationship between empathy and well-being among emergency nurses. J Emerg Nurs. 2015;41:323-8.

20. Gleichgerrcht $E$, Decety J. Empathy in clinical practice: how individual dispositions, gender, and experience moderate empathic concern, burnout, and emotional distress in physicians. PLoS One. 2013;8:e61526.

21. Zhang L, Wang A, Xie X, Zhou Y, Li J, Yang L, et al. Workplace violence against nurses: a cross-sectional study. Intern J Nurs Studies. 2017:72:8-14

22. Fields SK, Hojat M, Gonnella JS, Mangione S, Kane G, Magee M. Comparisons of nurses and physicians on an operational measure of empathy. Eval Health Prof. 2004;27:80-94.

23. Rasoal C, Jungert T, Hau S, Stiwne EE, Andersson G. Ethnocultura empathy among students in health care education. Eval Health Prof. 2009;32:300-13.

24. Boyle M, Williams B, Brown T, McKenna L, Molloy L, Lewis B. Attitudes towards patients by undergraduate health students. Nurs. 2010;35:270-3.

25. McKenna L, Boyle M, Brown T, Williams B, Molloy A, Lewis B, et al. Levels of empathy in undergraduate nursing students. Int J Nurs Pract. 2012;18:246-51.

26. Shariat SV, Habibi M. Empathy in Iranian medical students: measurement model of the Jefferson scale of empathy. Med Teacher. 2013;35:e913-e918.

27. Williams B, Boyle M, Earl T. Measurement of empathy levels in undergraduate paramedic students. Prehosp Disaster Med. 2013;28:145-9.

28. Williams B, Brown T, McKenna L, Boyle MJ, Palermo C, Nestel $D$, et al. Empathy levels among health professional students: a cross-sectional study at two universities in Australia. Adv Med Educ Pract. 2014;4:107-13.

29. Özakgül AA, Şendir M, Atav AS, Kızıltan B. Attitudes towards HIV/AIDS patients and empathic tendencies: a study of Turkish undergraduate nursing students. Nurse Educ Today. 2014;34:92933.

30. Hsiao CY, Tsai YF. Factors associated with the perception of family nursing practice among mental health nurses in Taiwan. J Fam Nurs. 2015;21:508-28.

31. Love MM, Smith AE, Lyall SE, Mullins JL, Cohn TJ. Exploring the relationship between gay affirmative practice and empathy among mental health professionals. J Multicult Couns Devel. 2015;43:83-96.

32. Mahoney S, Sladek RM, Neild T. A longitudinal study of empathy in pre-clinical and clinical medical students and clinical supervisors. BMC Med Educ, 2016;16:1-8.

33. Petrucci C, La Cerra C, Aloisio F, Montanari P, Lancia L. Empathy in health professional students: a comparative cross-sectional study. Nurs Educ Today. 2016;41:1-5.

34. Santamaría-García H, Baez S, García AM, Flichtentrei D, Prats $M$, Mastandueno $R$, et al. Empathy for others' suffering and 
its mediators in mental health professionals. Scient Reports. 2017;7:1-13.

35. Wang $C$, Wu $Q$, Feng $M$, Wan $Q$, Wu X. International nursing: research on the correlation between empathy and China's big five personality theory: implications for nursing leaders. Nurs Adm Q. 2017;41:E1-10.

36. Jurado MDMM, Pérez-Fuentes MDC, Gásquez Linares JJ, Martín ABB. Burnout in health professionals according to their selfesteem, social support and empathy profile. Front Psychol. 2018;9:424.

37. Penšek L, Selič P. Empathy and burnout in Slovenian family medicine doctors: the first presentation of Jefferson Scale of Empathy results. J Public Health. 2018;57:155-65.

38. Putrino N, Tabullo Á, Mesurado B, Minzi MCR. Are there differences in health professionals' empathy due to academic and clinical experience? Current Psychol. 2018:1-8.

39. Brown T, Williams B, Boyle M, Molloy A, McKenna L, Molloy L, et al. Levels of empathy in undergraduate occupational therapy students. Occup Ther Int. 2010;17:135-42.

40. Charles JA, Ahnfeldt-Mollerup P, Søndergaard J, Kristensen T. Empathy variation in general practice: a survey among general practitioners in Denmark. Int J Environ Res Public Health. 2018;15:433.

41. Gleichgerrcht E, Decety J. The relationship between different facets of empathy, pain perception and compassion fatigue among physicians. Front Behav Neurosci. 2014;8:243.

42. Khan MA, Niazi IM, Rashdi A. Emotional intelligence predictor of empathy in medical students. Rawal Med J. 2016;41:121-4.

43. Park $C$, Lee $Y$ J, Hong $M$, Jung $C H$, Synn $Y$, Kwack $Y S$, et al. A multicenter study investigating empathy and burnout characteristics in medical residents with various specialties. J Korean Med Sci. 2016;31:590-7.

44. Cripe LD, Perkins SM, Cottingham A, Tong $Y$, Kozak MA, Mehta R. Physicians in postgraduate training characteristics and support of palliative sedation for existential distress. Am J Hosp Palliat Care. 2017;34:697-703.

45. San-Martín M, Delgado-Bolton R, Vivanco L. Professionalism and occupational well-being: similarities and differences among Latin American health professionals. Front Psychol. 2017;8:63.

46. Hojat M, Mangione S, Nasca TJ, Cohen MJ, Gonnella JS, Erdmann JB, et al. The Jefferson Scale of Physician Empathy: development and preliminary psychometric data. Educ Psychol Meas. 2001;61:349-65.

47. Hojat M, Gonnella JS, Nasca TJ, Mangione S, Vergare M, Magee M. Physician empathy: definition, components, measurement, and relationship to gender and specialty. Am J Psychiatry. 2002;159:1563-9.

48. Davis $\mathrm{MH}$. Measuring individual differences in empathy: evidence for a multidimensional approach. J Pers Soc Psychol. 1983;44:113-36.

49. Jolliffe D, Farrington DP. Development and validation of the Basic Empathy Scale. J Adolesc. 2006;29:589-611.

50. Dökmen Ü. A new measurement model of the empathy and developing empathy by using psychodrama. J Educ Fac Ankara Univers. 1988;21:155-190.

51. Mehrabian A, Epstein N. A measure of emotional empathy. J Pers. 1972;40:525-43.

52. Davis $\mathrm{MH}$. Measuring individual differences in empathy: evidence for a multidimensional approach. J Pers Soc Psychol. 1983;44:113-26.

53. O'Sullivan $H$, van Mook $W$, Fewtrell $R$, Wass $V$. Integrating professionalism into the curriculum: AMEE Guide No. 61. Med Teach. 2012;34:e64-e77.

54. Redmond MV. The relationship between perceived communication competence and perceived empathy. Communic Mono. $1985 ; 52: 377-82$.

55. Derntl B, Finkelmeyer A, Eickhoff S, Kellermann T, Falkenberg DI, Schneider $F$, et al. Multidimensional assessment of empathic abilities: neural correlates and gender differences. Psychoneuroendocrinology. 2010;35:67-82.

56. Mestre MV, Samper $P$, Frías MD, Tur AM. Are women more empathetic than men? A longitudinal study in adolescence. Span J Psychol. 2009;12:76-83.

57. Hojat M, Gonnella JS, Mangione S, Nasca TJ, Veloski JJ, Erdmann $\mathrm{JB}$, et al. Empathy in medical students as related to academic performance, clinical competence and gender. Med Educ. 2002;36:522-7.

58. Kataoka HU, Koide N, Ochi K, Hojat M, Gonnella JS. Measurement of empathy among Japanese medical students: psychometrics and score differences by gender and level of medical education. Acad Med. 2009;84:1192-7.

59. Lam CB, Solmeyer AR, McHale SM. Sibling relationships and empathy across the transition to adolescence. J Youth Adolesc. 2012;41:1657-70

60. Cunico L, Sartori R, Marognolli O, Meneghini AM. Developing empathy in nursing students: a cohort longitudinal study. J Clin Nurs. 2012; 21:2016-25.

61. Esquerda M, Yuguero $O$, Viñas J, Pifarré J. La empatía médica, ¿nace o se hace? Evolución de la empatía en estudiantes de medicina. Aten Primaria. 2016;48:8-14.

62. Lam CB, Solmeyer AR, McHale SM. Sibling relationships and empathy across the transition to adolescence. J Youth Adolesc. 2012;41:1657-70.

63. Oliveira MDGS, Falcone EMO, Ribas Jr RC. A avaliação das relações entre a empatia e a satisfação conjugal: um estudo preliminar. Inter Psicol. 2009;13:287-98

64. Ribeiro CM, Pinho VD, Falcone EMO. A influência da raiva e da empatia sobre a satisfação conjugal. Aletheia. 2011:35-36.

65. Sardinha A, Falcone EMO, Ferreira MC. As relações entre a satisfação conjugal e as habilidades sociais percebidas no cônjuge. Psic Teor Pesq. 2009;25:395-402.

66. Rao N, Kemper KJ. The feasibility and effectiveness of online guided imagery training for health professionals. J Evid Based Complementary Altern Med. 2017;22:54-8.

67. Hogan R, Rossiter C, Catling C. Cultural empathy in midwifery students: Assessment of an education program. Nurse Educ Today. 2018;70:103-8.

68. Ozcan CT, Oflaz F, Bakir B. The effect of a structured empathy course on the students of a medical and a nursing school. Inter Nurs Rev. 2012;59:532-8.

69. Jolliffe D, Farrington DP. Development and validation of the Basic Empathy Scale. J Adolesc. 2006;29:589-611.

70. Hemmerdinger JM, Stoddart SD, Lilford RJ. A systematic review of tests of empathy in medicine. BMC Med Educ. 2007;7:24.

71. Hassanian ZM, Bagheri A, Sadeghi A, Moghimbegi A. Relationship between nurses' social responsibility and the quality of delivered nursing services to patients in Hamadan University of Medical Sciences, Iran. J Pak Med Assoc. 2019;69:99-102.

72. Madera-Anaya M, Tirado-Amador L, González-Martínez F. Factores relacionados con la empatía en estudiantes de Enfermería de la Universidad de Cartagena. Enferm Clin. 2016;26:282-9.

73. Asefi F, Delaram M, Deris F. Gap between the expectations and perceptions of students regarding the educational services offered in a school of nursing and midwifery. J Clin Diagn Res. 2017; 11:JC01-4.

74. Nabilou B, Khorasani-Zavareh D. The bridge between real and ideal: students perception on quality gap in reality and their educational expectations. Iran Red Crescent Med J. 2014;16:e14254.

75. Rahim Khanli M, Daneshmandi H, Choobineh A. The students' viewpoint on the quality gap in educational services. J Adv Med Educ Prof. 2014;2:114-9.

76. Batt-Rawden SA, Chisolm MS, Anton B, Flickinger TE. Teaching empathy to medical students: an updated, systematic review. Acad Med. 2013;88:1171-7.

77. Heje HN, Olesen F, Vedsted P. Patients' assessment of general practitioners. Association with type of practice. Ugeskr Laeger. 2010;172:1119-26

78. Asuero AM, Queraltó JM, Pujol-Ribera E, Berenguera A, RodriguezBlanco, T, Epstein RM. Effectiveness of a mindfulness education program in primary health care professionals: a pragmatic controlled trial. J Contin Educ Health Prof. 2014;34:4-12.

79. Meirovich A, Ber R, Moore M, Rotschild A. Student-centered tutoring as a model for patient-centeredness and empathy. Adv Med Educ Pract. 2016; 7:423-8.

80. Mathad MD, Pradhan B, Sasidharan RK. Effect of yoga on psychological functioning of nursing students: a randomized wait list control trial. J Clin Diagn Res. 2017;11:KC01-5.

\section{Correspondence:}

Madson Alan Maximiano-Barreto.

Departamento de Gerontologia - DGERO, Centro de Ciências Biológicas e da Saúde, Universidade Federal de São Carlos (UFSCar)

Rodovia Washington Luís, km 235

13565-905 - São Carlos, SP - Brazil

Tel.: +55 82999208149

E-mail: mmaximianopsi@gmail.com 